\title{
Rabbit, Run and Paul Ricoeur's Interpretation of Atheism
}

Rick Severson

There is this quality, in things, of the right way seeming wrong at first. To test our faith.

$$
\text { -John Updike, Rabbit, Run }{ }^{1}
$$

WhATEVER HAPPENED To Jack Eccles? Remember him? He was the broad-minded Episcopal minister who attempted to guide Harry "Rabbit" Angstrom's spiritual calisthenics in Rabbit, Run. Rabbit, the self-regarding ex-jock, crosses paths with Eccles after he dumps his wife Janice. As the pastor of Janice's family, Eccles agrees to have a chat with Rabbit. Their first meeting inspires mutual curiosity, which leads to further talks. The book develops around the unfolding of their relationship. With the dedication of a martyr - a martyr to liberal empathy and understanding, or to social gospel realism-Eccles pins his highest ministerial hopes on his ability to redeem, that is, reform, Rabbit. Rabbit, of course, is flattered by the attention. It is reminiscent of his basketball days. So why does Eccles disappear from John Updike's Rabbit series without a trace? After all, even Peggy Fosnacht, a neighbor Rabbit casually seduces, merits return in Rabbit Redux and Rabbit is Rich.

I want to offer an interpretation of Rabbit, Run that makes sense of Eccles's disappearance. The crux of my reading revolves around the suggestion that Rabbit, Run is an allegory of the death of God. Unlike the symbolism that points to heaven in Bunyan's The Pilgrim's Progress, Updike's figurative world is unconventionally earthbound. Rabbit's pilgrimage is a rediscovery of his instinctive or animal self, with harsh consequences. One of his human instincts, perhaps the most dangerous one (as Rabbit ascertains with Eccles's help), is his penchant for fleeing to God. "It's the strange thing about you mystics," Eccles remarks with this-worldly wisdom, "how often your little ecstasies wear a skirt" (p. 121). Rabbit's attempts to overcome irresponsibility 
are struggles against heaven. If he can exorcise his native instinct for Grace, he will have faced up to reality. The end to Rabbit's childishness begins to appear with his devastating insight that there is no God, and that it is possible to lose life (pp. 184-86). Eccles disappears with the pilgrim genre, and the Rabbit that reappears in Rabbit Redux is secular.

With God's death the pilgrim's journey ends forever, and the narrative form of finding oneself in finding God, especially with the help of a spiritual guide, becomes meaningless. Rabbit's loss-our loss - is the protection of a providential sky ("But maybe as a kid he walked under a protection that has now been lifted . . . ." [p. 274]). His gain is freedom from a doctrine of grace that requires belief in damnation (a la Kruppenbach, the Angstrom family pastor ${ }^{2}$ ) in order to ensure its own expediency. Recall Updike's introductory use of Pascal (pensee 507): "The motions of Grace, the hardness of the heart; external circumstances" (p. 5). Rabbit, Run appropriates Pascal's insight by documenting the "external circumstances" that inevitably link Grace and meanness. To the extent that Rabbit believes in God, he mistreats Janice. He must overcome his "hardness of the heart" by giving up his sugar daddy religion.

A theological question of interest is whether the critique of naive religious escapism must necessarily lead to a rejection of everything religious. Does the death of the pilgrim God, a God of cosmic morality, signal the end of every religious interpretation of reality? Here the work of Paul Ricoeur can be of some benefit. Ricoeur gives full assent to the critical loss of the immediacy of belief (what he calls first naiveté). ${ }^{3}$ Criticism-from Kant's critical philosophy to our everyday intellectual integrity-has proven overwhelming for both the precritical, naive believer and for Pascal's wagering soul. The urgency of the Pascalian wager for belief in God over against intellectual doubt has disappeared (or become suspect). ${ }^{4}$ Doubt, or suspicion, won the day handily. One need only recall Freud's summons for a science of humanity to replace religious illusion to see that as the case. Ricoeur, however, proposes a new wager that extends beyond criticism: one that can serve a secular or postreligious world.

Before I proceed with a discussion of Ricoeur's wager, tying it specifically to his understanding of atheism, let me say something about my intention for this essay. As I said, I want to present Rabbit, Run as an allegory of the death of God. Prior to that, however, I hope to suggest that the God who dies is of a specific kind or nature. In that regard, I will be following Ricoeur in both his appropriation and criticism of atheism. There are hidden misunderstandings in atheism that, once critiqued, can lead to the possibility of a postreligious faith 
(the second naiveté). What I intend, in a nutshell, is that Ricoeur cast a shadow of hope over Updike, and that Updike bring life to Ricoeur's hermeneutics. And who knows, Eccles may reappear in the next Rabbit book . . . perhaps in a new capacity.

\section{A Postreligious Faith?}

Man acts as though he were the shaper and master of language, while in fact language remains the master of man. Perhaps it is before all else man's subversion of this relation of dominance that drives his nature into alienation.

$$
\text { - Martin Heidegger, "Building Dwelling Thinking"5 }
$$

In "Religion, Atheism, and Faith,"6 Ricoeur conducts a philosophical investigation into the religious meaning of atheism. The essay is divided into two parts, dealing in turn with the themes of accusation and consolation. These themes, according to Ricoeur, represent the two main aspects of religion. He understands religion as a primitive structure of life grounded in the fear of punishment (accusation) and the desire for protection (consolation). In that this primitive structure needs to be overcome by a more genuine faith, atheism is a justifiable critique of religion. But hidden in its destructive purpose is also liberation-an opening to a faith situated beyond punishment and protection.

For Ricoeur, atheism means primarily the atheism of Nietzsche and Freud. Through analysis of human consciousness, they both unmasked and deciphered the illusions of religion. Their exegesis was accompanied by genealogical investigations that revealed the empty source of religious and ethical values. Among others, fear and desire were found to be instincts behind their production. Hence the conclusion that the concepts of good and evil have been created by means of projection within a situation of weakness (Nietzsche's slave morality) and dependency (Freud's yearning for the father).

Nietzsche's atheism in particular is mostly an attack on the accusation that characterizes the God of morality. For Ricoeur, that means atheism is left at an inconclusive point. The question that remains open is what sort of affirmation of life can follow atheism? Atheism not only says something about God-what God is not-it also says something about human beings. While it cannot be positive in its theology, it can and must become positive in its anthropology. The gist of Ricoeur's argument is that atheism is as naive in its anthropology as religion was in its theology. Thus the move to a more sophisticated reading of human experience is a move beyond the nihilistic legacy of atheism to the possibility of postreligious faith, or love of life.

Ricoeur exposes the naiveté of Nietzsche and Freud by following Heidegger and others in the turn to hermeneutics or, more generally, 
to language. In order to escape the alienating features of suspicion and mistrust that characterize atheism, a basic philosophical shift is made. The shift is away from a Cartesian metaphysics wherein self-reflective consciousness assumes that it is the presuppositionless starting point for human self-understanding. If the cogito is allowed to stand as the willful center from which human consciousness constitutes itself and all meanings and values, then Nietzsche's and Freud's suspicions are correct. But Ricoeur asks if there is such a thing as a presuppositionless philosophy. We come to consciousness already using a language; that fact ought to be significant. It is possible, argues Ricoeur, to get behind the crippling notion of a theory of values-how do values originate in consciousness? - by listening or harkening after a "Word" that is not at our disposition or command. By giving up sovereign consciousness's projects of the will (e.g., Nietzsche's will to power), we can rediscover an original ethical situation - a desire to be, a love of life -in the world of discourse that discloses life's possibilities.

Ricoeur practices a philosophy with presuppositions, which means he acknowledges the priority of language, and especially symbols, in the project of self-understanding. If we allow the power of words to inform us about our belonging to the world, we will be able to leave behind the cravings for protection and certainty that characterize the old moral vision. Beyond Providence and theodicy is another opportunity to be informed by our religious confessions. Of course we can no longer believe the religious confessions first hand because they are cast in the form of myth. Criticism has debunked the logic or scientific value of myth forever. But criticism has not, Ricoeur argues, discredited the symbolic power of myth. It is the religious symbols that can still speak to us of the sacred.

Symbolic discourse corresponds to the most primordial human experience, according to Ricoeur. There is no reality that we could be conscious of as prior to the reality presented in symbolic discourse: again, we come to consciousness already within a symbolic world. The symbol gives rise to all of our thinking and imagining, rooting us to our language world and to life. The most interesting implication of this insight into the priority of the symbol, and its function in constituting our very thoughts, is that our relations to the world (and ourselves) are always interpretive. There is no way out of a use of symbols, or a particular interpretation of the whole world. In order to understand, we must interpret. The desire for a presuppositionless philosophy must give way to a hermeneutics that already finds itself in the midst of beliefs that stem from particular symbols rooted in life. Acknowledging this situation, Ricoeur wagers on believing once 
again. He does not wager on the naive belief that subcribes to the reality of myths, but on the symbolic power of the Christian myths to lead us back to life itself. What Ricoeur actually bets on is a higher return in understanding by taking the path of belief. The second naiveté, beyond criticism by way of criticism, is a re-enactment of belief in the hope of better understanding, or of being reimmersed in a love of life and creation.

In other words, a postreligious faith, beyond atheism by way of atheism, listens once again for a sacred call, believing that the possibilities of life are best disclosed in religious symbols that already root us in life, and evoke our deepest desires.

\section{Rethinking the Eden Story}

Prior to the Enlightenment, it made little sense to speak of distinctive theologies and anthropologies. Theology reigned supreme, its portrayals of humanity unimpeachable. Since the Enlightenment, however, that has not been the case. The rise of anthropology as an independent science has often signalled the demise of theology. As matters now stand, theology requires the legitimation of anthropology. Hence Ricoeur's study of atheism as anthropology in his move to a postreligious faith: he discovers and overcomes atheism's alienating and naive features by proposing a new, more sophisticated anthropology. He does not appeal to theology in his critique, undertaking an apologetics; instead, the new anthropology opens the door for postreligious theology. Ricoeur appears to follow this simple credo: where the anthropology leads, the theology must follow. This formula will prove helpful as I return to Rabbit, Run.

In an effort to make use of Ricoeur's (Eliade's, Jung's) insight that we never escape or transcend symbolic discourse, I interpret Rabbit, Run as a return to Eden. The Garden of Eden myth contains some of our most powerful and significant symbols. What better place for a battle against heaven? Eden is the original scene of earthly habitation, the spot where naiveté was first lost. Death is the hard lesson of Eden, and personal responsibility. Also, a certain type of God died at Eden: never again would we believe that God ordinarily walks the earth as an embodied person. In order to overcome the God of cosmic morality, a return to Eden is necessary. To the extent that I demonstrate Rabbit's figurative revisitation of Eden, I will have presented Rabbit, Run as an allegory of the death of God.

Like Adam and Eve, Harry and Janice eventually have two children, one of whom dies prematurely. Adam and Eve's children came after expulsion from the Garden, whereas Harry, at least, reenters Eden in the sexual act. The instinct for procreation transports him back to the 
original creation, to the edge of paradise, and innocence. The zoological tenor of Updike's metaphors, most notably Harry's "Rabbit" nickname, suggests this return to instinctive innocence. Eden was the place of equality, or near equality, between humans and animals. Harry's "anthropology" is his body, his animal heritage, and by following its lead he reconnects with creation-its simple aliveness. Accompanying his innocent anthropology, Rabbit's theology also has a pristine, gushy quality. "I love it, I love it," Harry exclaims. "Palm Sunday is always blue. It makes the sap rise in my legs" (p. 96). There are no apples or snakes in this new Garden. Rather, the temptations are reversed: God, it would seem, has the opportunity to do something when baby Rebecca is drowning in the bathtub. God does nothing. This time around God is unable to sustain the Garden as a naive paradise. Unlike the original couple, Rabbit must learn to expel himself from Eden. How? By accepting responsibility for his family, and by fighting Providence as he fights "meanness of heart." While Providence was a real part of the old Garden, it has no place in the new one.

The text of Rabbit, Run can be broken into three parts according to the scenario outlined above. Part one is Rabbit's "run" for life, or his return to Eden; part two is his tragic attempt to sustain a life in paradise, building up to a showdown with God; and part three is his run away from Eden, especially the self-understanding and God he decides to leave there. In pagination, the three parts of my interpretation more or less correspond to Updike's own partitions.

In part one Rabbit seizes the chance to escape his fall from fame as a former basketball star. The obscurity of being married to Janice Springer is stifling. Rabbit wants to have a say in his life and its development. It oppresses him that the mere physical appearance of another generation is forcing him to grow up.

He stands there thinking, The kids keep coming, they keep crowding you up . . . . He doesn't want this respect, he wants to tell them there's nothing to getting old, it takes nothing. (pp. 9, 10)

Rabbit ducks out of the march of generations, abandoning Janice and Nelson. He takes a strange, all-night drive. This car trip begins his pilgrimage back to Eden (where the marching begins) and his animal self.

After his journey, Rabbit's instincts are sharp. His body sustains his newfound state of innocence. Like the old Adam, he needs a companion. We know Rabbit is in Eden when he takes up with Ruth, a hooker who lives across from a church and is offended that Harry believes in God. He, on the other hand, is offended that she tries to prevent getting pregnant. It spoils the childish immediacy that Rabbit 
has attained.

The shift to part two, Rabbit's tragic attempt to sustain a life in paradise, begins in earnest when Eccles arrives on the scene. They become fast friends, golf partners actually. In time, Eccles stakes the success of his ministry (the Christian Church's ministry?) on his ability to steer Rabbit back to a responsible life with Janice. Rabbit resists Eccles's efforts until Janice has their second child. That is when he suddenly recognizes the folly, and possible tragedy, of his fanciful search for God and paradise. "He is certain that as a consequence of his sin Janice or the baby will die. His sin is a conglomerate of flight, cruelty, obscenity, and conceit; a black clot embodied in the entrails of the birth" (p. 182). By whatever means one arrives at Eden, no one leaves except by sin. Paradise inevitably leads to tragedy. And in Rabbit's Garden, that means it is the search for God that leads inevitably to sin.

Rabbit quickly understands that there is no innocent relationship to God. His childish, wishful beliefs have linked him to terrible sins. But the sin is against Janice, not God. It is because of God that he runs and incurs guilt. So Rabbit puts two and two together:

There is no God: Janice can die: the two thoughts come at once, in one slow wave. He feels underwater, caught in chains of transparent slime, ghosts of the urgent ejaculations he has spat into the mild bodies of women. (p. 184)

Just as having care-free, instinctive sex with Ruth sustained paradise, Janice's having their baby suddenly shatters it.

It is one thing for Rabbit to have an insight about there not being a God, quite another to allow it to shape his life. Finally, in part three, Rabbit must expel himself from Eden. That proves difficult. Even though they get back together, Janice and Rabbit fight. When Rabbit runs to Ruth again, Janice is devastated. She drinks too much and the baby drowns in the bathtub. Rabbit comes back. The full weight of Eden rests upon him: the presumption of faith, the harsh reality of death. But still he tries to cling to his naive faith.

The situation is assessed best by Mr. Tothero, Rabbit's former coach. He tells Rabbit that right and wrong are not dropped from the sky, that we are responsible for ourselves. Here the message of Rabbit, Run fully connects with the modern legacy that Ricoeur talks about: naive religion must give way to the critique of atheism, theology to anthropology. It is Tothero, not Eccles, who is able to deliver the most revealing message. As Updike tells us, Tothero's revelation chills Rabbit. Why? Because "he wants to believe in the sky as the source of all things" (p. 258). Instinct, luck and time run out for Harry "Rabbit" Angstrom. When he flees again, for the last time, he is fleeing Eden. Eccles's failure to guide Rabbit back to a responsible life with Janice- 
Rabbit makes a pass at Mrs. Eccles! - signals the death of the pilgrim God.

\section{Conclusion}

Ricoeur's interpretation of atheism and Rabbit's pilgrimage pass similar milestones. From naive religion and from Eden as a symbol of paradise, they move to a more sophisticated understanding of humanity that spells the death of the God of cosmic morality. In the case of Ricoeur, however, there is an additional step. He wants to suggest an opening for a new, postreligious faith beyond the naiveté of atheism. While this further move by Ricoeur probably cannot be matched in Rabbit, Run, it can be anticipated there.

The problem with atheism has been its inability to overcome its own nihilistic tendencies: in giving up paradise, it also gives up the tree of life. That is not the case with Rabbit, Run. As Mrs. Smith tells Rabbit when he quits his temporary gardening job,

That's what you have, Harry: life. It's a strange gift and I don't know how we're supposed to use it but I know it's the only gift we get and it's a good one. (p. 207)

If Eden can no longer represent paradise, it may yet speak as a symbol of the gift of life. It is possible that Harry Angstrom, through reinterpretation of these events and from the vantage point of a second naiveté, will hear a call to faith again. Not because he has unfulfilled childhood wishes, but because he seeks a better understanding of himself.

So how about it, Mr. Updike: where does Eccles disappear to? What have you done with him? Is there a role he can still play as Harry and Janice approach their old age?

\section{NOTES}

1 John Updike, Rabbit, Run (New York: Ballantine Books Edition of Fawcett Crest Edition, 1982 and 1962), 37. (All subsequent references to Rabbit, Run will be indicated by page numbers in this edition.)

2 Kruppenbach is the Angstrom family pastor with whom Eccles (the Springer family pastor) disputes. "Don't you believe in damnation?" (p. 158) Kruppenbach asks Eccles when the latter tries to discuss a way of helping Harry and Janice.

3 I refer to "The Symbol Gives Rise to Thought," the famous concluding chapter of The Symbolism of Evil, trans. Emerson Buchanon (Boston: Beacon Press, 1969).

4 I am suggesting that the distance between Pascal and Ricoeur is of the same importance as the distance between Bunyan and Updike. Between the 17th and 20th centuries stands the modern experiment.

5 Martin Heidegger, "Building Dwelling Thinking," trans. Albert Hofstader, Poetry, Language, Thought (New York: Harper and Row, 1975), 146.

6 Paul Ricoeur, "Religion, Atheism, and Faith," The Conflict of Interpretations, ed. Don Ihde (Evanston: Northwestern University Press, 1974), 440-467. 